\title{
Skolämnen och moralisk fostran: En komparativ studie av samhällskunskap och livskunskap
}

\author{
Joakim Landahl
}

\begin{abstract}
School subjects and moral education: A comparative study of civics and life-skills This article is concerned with two school subjects that were introduced in Swedish schools during the 20th century: civics and life-skills. Drawing on textbooks in civics from the 1950s to the 1960 s and textbooks in life-skills from the 2000s, the aim is to analyse and compare the morality conveyed in the respective school subjects during its introductory years. It is argued that civics and life-skills can be used to get a grip of differences between different historical contexts, since the two school subjects emerged in two different time periods. Civics emerged as a school subject for the comprehensive schools during the middle of the 20th century, and might therefore be labeled as a typically "modern" school subject, whereas life skills emerged in the late 1990s, and might therefore be labeled a "late modern" school subject. Given that these two school subjects emerge as novelties in two different time periods, they can be used to discuss how the meaning of moral education in schools is related to general social tendencies.
\end{abstract}

\section{Keywords}

moral education, modernity, school subjects, civics, life-skills

moralisk fostran, modernitet, skolämnen, samhällskunskap, livskunskap

Moralisk fostran förstås ofta i termer av socialt återskapande. Enligt en vanlig föreställning innebär fostran att normer överförs från en äldre generation till en yngre. Men moralisk forstran har också en omvänd riktning. Särskilt i vissa historiska skeden har strävan efter förnyelse varit påtaglig. Nya moraliska ideal har förfäktats samtidigt som nya tekniker utvecklats för att forma en delvis ny typ av människa. Ett sätt att förverkliga en sådan förnyelse är att inrätta ett nytt skolämne. Genom en sådan introducering ges skolan på ett relativt påtagligt sätt ett nytt uppdrag, och inom ramen för detta nya uppdrag kan nya idéer om elevers fostran utvecklas.

I denna artikel studeras två moraliskt fostrande skolämnen som infördes i Sverige under 1900-talet: samhällskunskap och livskunskap. Syftet med undersökningen är att analysera och jämföra den moral som förmedlats inom ramen för dessa två skolämnen. Vilken typ av elev var det som man ville forma och vilken typ av samhälle avsåg undervisningen därmed vara med om att skapa? Utgångspunkten är att de båda ämnena uppvisar både likheter och skillnader som gör dem intressanta att jämföra. En första likhet är att ämnena har introducerats under andra hälften av 1900-talet: samhällskunskap introducerades vid mitten av 1900-talet, livskunskap i slutet av 1900-talet. Den andra likheten består i att de båda innehållit en tydlig

Joakim Landahl is Associate Professor of Pedagogy at the Department of Education, Stockholm University, Sweden.

Email: joakim.landahl@edu.su.se 
moralisk komponent. Det är skolämnen som har tillskrivits en viktig betydelse för att etablera social ordning. Men samhällskunskap och livskunskap uppvisar också skillnader, och ambitionen med denna artikel är att diskutera dessa skillnader, i syfte att precisera hur idéer om moralisk fostran har förändrats över tid. Samhällskunskap och livskunskap kan i detta avseende användas för att belysa skillnader mellan två faser i det moderna. Detta hänger samman med att ämnenas tillblivelse äger rum i olika historiska kontexter. Samhällskunskap utvecklas som ett ämne för enhetsskolan och grundskolan i mitten av 1950-talet, och kan således beskrivas som ett typiskt "modernt" ämne. Livskunskap introduceras i Sverige under 1990-talet och kan beskrivas som ett "senmodernt" ämne. Genom att dessa ämnen är så starkt knutna till olika tidsperioder kan de därför användas för att diskutera hur skolämnen utvecklas i samspel med den allmänna samhällsutvecklingen. Nya skolämnen kan belysa hur skolan både speglar och formar vissa ideal och förhållningssätt i ett visst samhälle under en viss tidsperiod. Sådana tendenser som på en generell nivå diskuteras inom samhällsteori - exempelvis senmodernitetens tendenser till individualisering, terapeutisering och förlorad tilltro till framtiden - kan illustreras och kvalificeras utifrån analyser av skolböcker. ${ }^{1}$

För att förtydliga studiens fokus kan det vara en poäng att analytiskt skilja mellan två former av fostran i skolan: den som utgår från skolans arbetsformer och den som utgår från dess innehåll. Fostran via arbetsformer består av krav på anpassning till vissa institutionella villkor: punktlighet, förmåga att sitta still, lämna in uppgifter, planera skolarbetet etc. ${ }^{2}$ Fostran via innehåll handlar om de dispositioner och värderingar som förmedlas via skolans kunskapsinnehåll, exempelvis genom dess skolämnen och dess läromedel. ${ }^{3}$ Traditionellt har kristendom innehaft den centrala rollen i denna innehållsbaserade fostran, även om man inte ska underskatta den roll som andra ämnen spelat, exempelvis historia och gymnastik. ${ }^{4}$ Under 1900-talets gång förlorade emellertid religionen successivt sin roll som självklar moralförmedlare. ${ }^{5}$

1 Ulrich Beck och Elisabeth Beck-Gernsheim, Individualization: Institutionalized Individualism and its Social and Political Consequences (London: SAGE, 2002); Frank Furedi, Therapy Culture: Cultivating Vulnerability in an Uncertain Age (London: Routledge, 2004); Anthony Giddens, Modernity and Self-Identity (London: Polity Press, 1991); Zygmunt Bauman, Liquid Modernity (London: Polity Press, 2000).

2 Se Philip W. Jackson, Life in Classrooms (New York: Holt, Rinehart \& Winston, 1968). De krav som ställs på eleverna är emellertid inte statiska, utan förändras i takt med exempelvis undervisningens metodik. Övergången från växelundervisning till lärarledd undervisning innebar exempelvis en förändrad syn på skolans fostran, och de senaste decenniernas ökade inslag av eget arbete innebär också att skolans disciplinering ändrar karaktär. Se Joakim Landahl, "The Eye of Power(-lessness): On the Emergence of the Panoptical and Synoptical Classroom," History of Education 42, no. 6 (2013), 803-21; Eva Österlind, Disciplinering via frihet. Elevers planering av sitt eget arbete (Uppsala: Acta Universitatis Upsaliensis, 1998).

3 Det mest klassiska bidraget till denna typ av analys torde vara Herbert Tingsten, Gud och fosterlandet: Studier i hundra års skolpropaganda (Stockholm: Norstedts, 1969).

4 Om gymnastik respektive historia, se t.ex. Jens Ljunggren, Kroppens bildning: Linggymnastikens manlighetsprojekt 1790-1914 (Eslöv: Symposion, 1999) och Janne Holmén, Den politiska läroboken: Bilden av USA och Sovjetunionen i norska, svenska och finländska läroböcker under kalla kriget (Uppsala: Acta Universitatis Upsaliensis, 2006).

5 Kring skolans sekularisering, se exempelvis Bengt Thelin, Exit eforus: Läroverkens sekularisering och striden om kristendomsundervisningen (Stockholm: LiberLäromedel/Utbildningsförlaget, 1981); Lennart Tegborg, Folkskolans sekularisering 1895-1909: Upplösning av det administrativa sambandet mellan folkskola och kyrka i Sverige (Uppsala: Studia historico-ecclesiastica Upsaliensia, 1969). 
Därmed växte också utrymmet för nya aktörer och för nya skolämnen att förmedla en delvis ny moral. "Moralens entreprenörer", för att låna sociologen Howard Beckers utryck, kunde kliva in på skolans område och formulera delvis nya bud riktade mot landets elever. ${ }^{6}$ De två skolämnen som jämförs i denna artikel är en del av denna mer sekulariserade tid, där moralen inte huvudsakligen byggs på religiösa uppfattningar, utan grundas i något annat.

Såväl samhällskunskap som livskunskap är tämligen välstuderade ämnen. När det gäller samhällskunskapsämnet är det framförallt Tomas Englund som i Sverige bedrivit forskning kring ämnets historia. ${ }^{7}$ Även livskunskapsämnet har på senare år blivit föremål för ett flertal studier. ${ }^{8}$ Ämnet är inte ett isolerat svenskt fenomen, utan speglar en internationell rörelse mot vad som kallats terapeutisk utbildning eller rentav en generell terapeutisk kultur. ${ }^{9}$ I relation till den existerande forskningen bidrar föreliggande artikel framförallt med ett komparativt perspektiv. Genom att ställa två likartade ämnen mot varandra blir det möjligt att se vari deras särart som moraliskt fostrande ämnen består.

Undersökningens centrala källor är läromedel och handledningar i samhällskunskap och livskunskap, vilka har analyserats med avseende på vilken moral de förmedlar till eleven. Läromedel är en tacksam källa om man vill undersöka vilken moral ett skolämne förmedlar i praktiken, så som den ser ut när den presenteras för eleven. Den moralen kan delvis knytas till ideal som uttrycks i olika typer av styrdokument men kan inte reduceras till att vara effekter av dem, utan förvaltar dem med vidareutvecklingar, preciseringar och tillägg. Som läromedelsforskningen visat har dessutom läromedel ofta en mycket styrande roll i undervisningen. Läroböcker når ett stort antal elever och kan ha en stor påverkan på hur lärare lägger upp undervisningen och vilket urval som presenteras för eleverna. ${ }^{10}$

Att föreliggande undersökning använder sig av läromedel som källa motiveras dessutom av att de erbjuder en möjlighet till jämförelse mellan två skolämnen i olika tider som annars skulle ha varit svår att genomföra. Ett samtida ämne som livskun-

6 Howard S. Becker, Utanför: Avvikandets sociologi (Lund: Arkiv, 2006).

7 Se även Birger Bromsjö, Samhällskunskap som skolämne: Målsättningar, kursinnehåll och arbetssätt på den grundläggande skolans högstadium (Stockholm: Stockholms universitet, 1965); Ronald W. Evans, The Social Studies Wars: What Should We Teach the Children? (New York: Teachers College Press, 2004).

8 Se t.ex. Camilla Löf, Med livet på schemat: Om skolämnet livskunskap och den riskfyllda barndomen (Lund: Lunds universitet, 2011); Åsa Bartholdsson och Eva Hultin, red., Sociala relationer, värdegrund och lärarprofessionalitet (Malmö: Gleerups, 2015); Sara Irisdotter Aldenmyr, "Lärarprofessionen och arbetet med livskunskap i grundskolan," Utbildning \& Demokrati 19 (2010), 39-57; Magnus Dahlstedt, Andreas Fejes och Elin Schönning, "The Will to (De)liberate: Shaping Governable Citizens Through Cognitive Behavioural Programmes in School," Journal of Education Policy 26, no. 3 (2011), 399-414.

9 Furedi (2004); Kathryn Ecclestone och Dennis Hayes, The Dangerous Rise of Therapeutic Education (Abingdon, Oxon: Routledge, 2009).

10 För en översikt över aktuell läromedelsforskning, se Niklas Ammert red., Att spegla världen: Läromedelsstudier i teori och praktik (Lund: Studentlitteratur, 2011). Mot bakgrund av lärobokens inflytande över undervisningen kan man förstå olika sätt att styra tillgången till läromedel, exempelvis genom statlig förhandsgranskning av läromedel, eller via föreningarna Nordens läroboksrevision. Se Anna Johnsson Harrie, Staten och läromedlen: En studie av den svenska statliga förhandsgranskningen av läromedel 1938-1991 (Linköping: Linköpings universitet, 2009); Henrik Åström Elmersjö, Norden, nationen och historien: Perspektiv på föreningarna Nordens historieläroboksrevision 1919-1972 (Lund: Nordic Academic Press, 2013). 
skap har tidigare studeras med metoder som deltagande observation, intervjuer och enkäter, men motsvarande undersökningar kan inte göras på samhällskunskapsämnets äldre förlagor. En jämförelse kan heller inte ta utgångspunkt i läroplaner, eftersom livskunskap aldrig haft status som skolämne i läroplanen och inte heller haft någon nationell kursplan.

Urvalet av läromedel har styrts av studiens komparativa ansats. Ambitionen har varit att jämföra två nya skolämnen med moraliskt fostrande ambitioner och därför har urvalet av samhällskunskapsböcker koncentrerats till 1950- och 1960-talen, medan läromedlen i livskunskap är från 2000-talet. På så sätt består studien av två relativt distinkta undersökningsperioder. I urvalet har använts 16 läromedel i samhällskunskap, varav 12 är läroböcker och fyra är böcker med arbetsuppgifter åt eleverna. Läromedlen är huvudsakligen avsedda för folkskolan eller enhetsskolan, och riktar sig till låg-, mellan- och högstadium; några användes även i realskola och flickskola. Därtill har även använts två läromedel i medborgarkunskap, det skolämne som inrättades i fortsättningsskolan 1919, och som är en föregångare till samhällskunskapsämnet. ${ }^{11}$ I livskunskap är utbudet av läromedel annorlunda. Här har en författare, Birgitta Kimber, spelat en dominerande roll, genom att hon skrivit läromedel som sträcker sig från förskoleklass till gymnasiet. Det är endast dessa läromedel, samt tillhörande handledningar, som använts för undersökningen av livskunskapsämnet.

\section{Samhällskunskap}

Precis som att sociologin upptäckte samhället på 1800-talet kan man säga att pedagogiken kom att upptäcka samhället under 1900-talet. I takt med att den religiö-

11 Följande böcker ingår i urvalet: Stellan Arvidson och Karl Lindblom, Samhällskunskap för skolans avslutningsklasser (Stockholm: Svenska bokförlaget/Bonniers, 1953); Sven-Eric Barck, Arbetsbok $i$ samhällskunskap. D. 1, Skolan, hemmet, fritiden: För årskurs 7 i enhetsskolan (Gävle: Skolförlaget, 1961); Sven-Eric Barck, Arbetsbok i samhällskunskap. D. 2, Arbetslivet, kommunerna, världsproblemen: För årskurs 8 i grundskolan (Gävle: Skolförlaget, 1956); Sixten Björkblom och Arnold Helgesson, Samhällsundervisningen: Studieplan i samhällskunskap för sjunde-nionde skolåren vid pedagogisk försöksverksamhet i enlighet med beslut av 1950 års riksdag (Stockholm: Sv. Bokförlaget, 1952); Sixten Björkblom, Vårt svenska samhälle: Lärobok i samhällskunskap (Stockholm: Almqvist \& Wicksell, 1953); Sixten Björkblom, Samhällskunskap för grundskolan: Årskurs 7, Elevhäfte. Stockholm: Almqvist \& Wiksell, 1964); Sixten Blomquist, Henry Pederby och Algot Teng, Samhällskunskap för enhetsskolan och folkskolan: Årskurs 4-6. 2. uppl. (Stockholm: Bergvall, 1960); Martin Bäcklin och Axel Runestam, Samhällskunskap: Arbetsuppgifter. För årskurs 7. Stockholm: Skrivrit, 1961); Martin Bäcklin och Axel Runestam, Samhällskunskap: Arbetsuppgifter. För årskurs 8 (Stockholm: Skrivrit, 1963); Valter Elgeskog, Olof Skarhed och Karl Lindblom, Barnen möter samhället: Handledning vid undervisning i samhällskunskap på folkskolans och enhetsskolans mellanstadium: [klasserna 4-6] (Stockholm: Svenska bokförlaget/Bonnier, 1955); Evald Fransson, Demokratins samhälle: Lärobok i samhällskunskap för folkskolans och enhetsskolans högstadium samt för real- och flickskolor (Stockholm: Natur \& Kultur, 1956); Nils Helger, Medborgarbok för ungdomsskolor, under medverkan av Bengt Helger och Torsten Helger, 39. uppl. (Uppsala: Lindblad, 1955); Gösta Johannesson, Vårt samhälle: Lärobok i samhällskunskap för realskolan och enhetsskolans högstadium (Lund: Gleerups, 1953); Rune Näslund, Vi och vårt samhälle: Samhällskunskap för klasserna 4-6, 4. uppl. (Stockholm: Carlson, 1955); Henry Pettersson-Pederby, Folkskolans samhällslära: Klass 7-8 jämte fortsättningsskolan, 2 uppl. (Stockholm: Svenska bokförlaget, Norstedts, 1954); Värner Rydén, Medborgarkunskap för fortsättnings- och andra ungdomsskolor, 8. uppl. (Stockholm: Norstedt, 1937); Arvid Rosén och Oscar Jonsson, Samtal om samhället: Samhällskunskap för klass 4-6, 2. uppl. (Stockholm: Svenska bokförlaget/Norstedt, 1957); Roland Severin och Thorbjörn Rippe, Samhällsboken: Samhällskunskap för grundskolan. Årskurs 4-6 (Stockholm: Svenska bokförlaget/ Bonniers, 1963); Erik Thurén och Lars Lindholm, Den unge medborgaren: Lärobok i samhällskunskap för folkskolans och enhetsskolans högstadium, 15. omarb. uppl. (Stockholm: Bergvalls, 1956). 
sa undervisningen successivt blev mindre framträdande skapades ett utrymme för andra ämnen att göra anspråk på den moraliska fostran av eleverna. Tendenser till en stärkning av de samhällsorienterande inslagen i undervisningen märktes redan 1919 då ämnet medborgarkunskap infördes i den påbyggnad på folkskolan som fick namnet fortsättningsskolan. Även i de lägre åldrarna förekom samhällsorienterande undervisning, inom ramen för ämnet hembygdskunskap. ${ }^{12}$ I mitten av 1900-talet höjdes emellertid röster för att ytterligare markera behovet av kunskaper om samhället. Ämnet samhällskunskap tillmättes stor betydelse av 1946 års skolkommission, som ville inrätta det som ett nytt ämne i den nya enhetsskolan. I sin argumentation för det nya ämnet pekade kommissionen på att det tillkommit så många nya inslag i folkskolans undervisning som saknade självklar tillhörighet i något av de dåvarande skolämnena: nykterhetsundervisning, sexualundervisning, trafikundervisning, sparsamhetsuppfostran och yrkesorientering. Skolkommissionen menade att utvecklingen i denna riktning behövde fortsätta, så att eleverna kunde bli bättre anpassade till det man kallade "livets svårigheter."

Uppgiften är så pass betydelsefull för elevernas fostran till samhällsmedborgare, att ett särskilt skolämne härför bör inrättas, samhällskunskap, som bör avlösa hembygdsundervisningen i färrde klassen och sedan kvarstå på schemat till och med den obligatoriska skolans avslutningsklass. ${ }^{13}$

Genom att samhällskunskapsämnet var nytt så fanns det möjligheter att fylla det med ett nytt innehåll. Ambitionerna från skolkommissionen vittnar om att det fanns mängder av inslag som ansågs passa in i det nya ämnet. I de läromedel som här har gåtts igenom ser vi också ett vittomfattande skolämne som innehåller teman som hemmet, fritiden, föreningskunskap, yrkesval, trafikfrågor, kommunen, staten, rättsväsendet, internationell samverkan, pengar, sparsamhet, försäkringar samt vett och etikett.

\section{Moralens centrum: samhället}

Samhällskunskapsämnets moralinnehåll handlade om individens relation till samhället. Fostran var liktydig med att eleven skulle lära sig om samhället och på så sätt bli en god samhällsmedborgare. Denna syn på fostran byggde i sin tur på åtminstone två föreställningar om samhället. För det första beskrevs samhället i termer av en gemenskap, och för det andra beskrevs samhället som bestående av ett antal koncentriska cirklar.

Att samhället var en gemenskap beskrevs inte sällan redan i inledningen till läroböckerna. ${ }^{14}$ Det påpekades gärna att ordet samhälle betydde gemenskap, och böckerna i stort förmedlade samma budskap. Denna positiva värdering av ämnets studieobjekt gjorde ämnet speciellt. Samhället var inte ett neutralt objekt att utveckla kunskaper om, utan ett objekt som eleverna skulle utveckla positiva känslor till. Denna emotionella ambition var än tydligare i det tidigare medborgarskapsämnet,

12 Anna Larsson, "Samhällskunskap," i Utbildningshistoria: En introduktion, red. Esbjörn Larsson och Johannes Westberg, 249-58. (Lund: Studentlitteratur, 2011).

13 SOU 1948:27, 1946 års Skolkommissions betänkande med förslag till riktlinjer för det svenska skolväsendets utveckling (Stockholm: Ecklesiastikdepartementet, 1948), 6-7.

14 T.ex. Severin och Rippe (1963), 3. 
som präglades av en påtaglig patriotism. I förordet till Nils Helgers Medborgarbok för ungdomsskolor beskrevs samhället så här: "Vi är alla medborgare i ett samhälle, och samhället lever, arbetar och växer för medborgarnas trevnad och allas bästa." ${ }^{15}$ Men även i lite senare samhällskunskapsböcker kom den positiva bilden av samhälle att dominera, om än med en mer nedtonad entusiasm inför samhället. Fostran till att uppskatta denna sammanhållning skedde bland annat genom att skildra samhällets ljusa sidor. Rubriken "vad samhället ger" kunde exempelvis följas av beskrivningar av sjukvård, utbildning och kyrkans arbete. ${ }^{16}$ Implicit fanns därmed bilden av samhället som en generös givare av välfärdsförmåner som medborgaren förväntades känna tacksamhet inför. Denna fostran till tacksamhet gällde även själva rollen som elev. Vissa böcker tog upp frågan om vad elever kostar samhället. ${ }^{17}$ Därmed förmedlades en bild av barnet som satt i skuld till samhället, men en skuld som i långa loppet kunde återbetalas: "Genom att sköta ett arbete bra när man blir vuxen, kan man på sätt och vis betala igen vad man får gratis under sin skoltid." ${ }^{18}$ Detta intryck av ett välfungerande samhälle förmedlades också visuellt. Läroböckernas illustrationer kunde på olika sätt exemplifiera hur samhället successivt gick mot en ljusare framtid. Det kunde vara ett fotografi på ett nyuppfört lasarett, en graf över hur mycket tuberkolosen minskat över tid eller en bild på brandkåren i färd med att släcka en eld med den nya moderna motorsprutan.

De samhällskritiska inslagen var betydligt mer ovanliga. Samhällskunskap var endast i begränsad utsträckning ett ämne som ägnade sig åt samhällets problem. När sociala problem behandlades var det ofta i termer av problem som kunde bemästras, och som i historiskt perspektiv varit större. Ett undantag är Evald Franssons Demokratins samhälle. I sitt förord påpekar Fransson, i ett eko av tidigare medborgarkunskapsböcker, att samhällets positiva strävanden "självklart" skulle "starkt framhävas och belysas". Men samtidigt menar han att samhällets många problem skulle lyftas fram, något som exemplifierades med "medborgarbildningens och livsföringens brister samt riskerna av statens oavbrutet växande makt i vår tid [...]." ${ }^{\prime 19}$ En sådan programförklaring var ovanlig i läroböcker i samhällskunskap, även om det de facto fanns en hel del inslag av socialt problematiserande i böckerna. Ofta var detta problematiserande åtföljt av ett moraliserande riktat mot individen, där de sociala problemen beskrevs i termer av dålig karaktär och dåliga vanor. Detta innebar att de sociala problemen, paradoxalt nog, inte framstod som sociala produkter, utan snarare som produkter av asocialitet. Bilden av samhället som en relativt välfungerande gemenskap utmanades inte.

Denna positiva bild av samhället kompletterades med en specifik idé om vad ett samhälle var. Idén var att samhället kunde liknas vid en uppsättning koncentriska cirklar. Samhället kunde delas in i olika sfärer, från hemmet, via exempelvis församlingen, kommunen och staten till världssamfundet. Ett flertal läromedel i samhällskunskap inleds med ett kapitel om hemmet. ${ }^{20}$ Den koncentriska samhällsmodellen

\footnotetext{
15 Helger (1955), 5.

16 Elgeskog, Skarhed och Lindblom (1955), 27; Severin och Rippe (1963), 158-73.

17 Elgeskog, Skarhed och Lindblom (1955), 28; Severin och Rippe (1963), 40; Barck (1961), 14.

18 Severin och Rippe (1963), 40.

19 Fransson (1956), 10.

20 Björkblom och Helgesson (1952), Rydén (1937); Pettersson-Pederby (1954); Näslund (1955); Fransson (1956); Severin och Rippe (1963); Thurén och Lindholm (1956).
} 
byggde på idén om att samhälle är något som existerar i olika skalor. Samhället existerar inte i singularis, utan återfinns i såväl stor som miniatyrartad skala. Även de små enheterna är således samhällen. I ett läromedel står det exempelvis: "Familjen består vanligen av far, mor och barn. När far och mor gifter sig, bildar de ett samhälle - två människor, fler behövs det inte för att ett samhälle ska uppstå.,"21

Konsekvensen av samhällskunskapsämnets breda bild av samhället var att gränsen mellan privat och offentligt blev oskarp. I motsats till föreställningen om hemmet som en privat sfär kom hemmet att beskrivas som ett av många samhällen. En konsekvens av detta var att utrymmet för moraliserande perspektiv blev större. Grundtanken var att hemmet var en plats där man lärde sig att ta hänsyn till varandra, vilket samhällslivet i stort vilade på. I familjen var man tvungen att samarbeta, och den individuella viljan behövde böja sig för kollektivets bästa. En lärobok beskrev det så här: "Familjerna är alltså de minsta byggstenarna, varav vårt samhälle är uppbyggt. Genom att familjelivet på många sätt liknar livet i samhället, är familjen väl lämpad att fostra barnen till goda samhällsmedlemmar."22 I ett läromedel beskrevs familjen som samhällets grundval. Här nyttjades en biologisk liknelse: liksom att kroppen är uppbyggd av celler är samhället uppbyggt av familjer. När cellerna är friska är kroppen frisk, och på samma sätt förhåller det sig med samhället. "I hemmen läggs grunden till kroppslig och andlig hälsa, till arbetssamhet och rättrådighet, till pliktkänsla och goda seder." ${ }^{23}$ Exemplen på hur hemmet fostrade kunde mångfaldigas. Läroböckerna tog bland annat upp värdet av sparsamhet, gott bordskick, ordningsamhet och respekt för föräldrarna.

Ett centralt värde i flera samhällskunskapsböcker var att ta hänsyn till andra människor. Detta kunde beskrivas som själva kärnan i människans socialitet. Genom att kontrastera livet på en öde ö med livet i ett samhälle hävdade exempelvis ett läromedel att hänsyn är det som krävs i ett samhälle. ${ }^{24}$ Att visa hänsyn handlade ofta om vett och etikettsfrågor, exempelvis att inte störa eller vara i vägen för andra människor. Den som sträckte sig över andra efter maten, spelade musik, dansade sent $\mathrm{i}$ en lägenhet eller pratade högt $\mathrm{i}$ en spårvagn visade inte hänsyn. Det kunde också formuleras på följande sätt:

Brukar du vara slarvigt klädd, okammad och smutsig, ha dålig hållning, köra ned händerna i byxfickorna, vara tvär och tjurig, titta under lugg, uppträda nonchalant?

Då tar du ingen hänsyn till din omgivning och är otrevlig att vara tillsammans med. ${ }^{25}$

En sentida läsare kan reagera över ämnesinnehållet. Vad hade egentligen detta att göra med samhällskunskap? Ett möjligt svar kan ta fasta på den koncentriska samhällsmodellen. Denna vilade, som vi såg, på föreställningen om att samhället har olika skalor och uppenbarelseformer, där beteendet inom en sfär kunde ses som en träning inför en annan sfär.

\footnotetext{
21 Rosén och Jonsson (1957), 2.

22 Johannesson (1953), 8.

23 Thurén och Lindholm (1956), 2.

24 Björkblom (1953), 9. Om värdet av hänsyn, se även Rosén och Jonsson (1957), 33f, 55; Thurén och Lindholm (1956), 3, 22f.

25 Blomquist, Pederby och Teng (1960), 57.
} 


\section{Moralisk kompetens: lagar och regler}

När moraliska normer förmedlades i samhällskunskapsböcker var det i form av ideal som hade självklarhetens prägel. Ett uttryck för detta är ett stort intresse för lagar, brott och straff. Samhällskunskapsböcker tilldelade ofta rättsväsendet en central position. Det var en tradition som fördes vidare från äldre böcker i medborgarkunskap. I Värner Rydéns bok i medborgarkunskap drogs slutsatsen att tilltron till lagen var något av ett svenskt kännetecken. "Lagbunden ordning har varit det svenska samhällets styrka. När laglösheten hotat, har fördärvet varit nära." ${ }^{26}$ När Rydén sammanfattade sin bok i medborgarkunskap var det således lagen som stod i centrum. Det var här samhällets kärna låg. Laglydnad beskrevs därför följdenligt som den främsta av medborgerliga plikter. Även senare läroböcker i samhällskunskap skulle komma att lägga stor vikt vid rättssamhället. Ett läromedel beskrev respekten för lagar som kärnan i den mänskliga socialiteten: "Bodde vi ensamma på en ö, skulle lag och förordning vara överflödiga. Nu bor vi i ett samhälle och måste ta hänsyn till varandra eller tvingas till det. Alla kan inte få följa sin egen vilja. Det skulle sluta med fullständig oreda. Vi måste underordna oss - lyda, även om det är en uppoffring för oss." ${ }^{27}$

Den moraliska tonen var inte alltid så explicit, men ett implicit budskap om laglydnadens betydelse förmedlades genom att läromedlen relativt grundligt gick igenom hur det rättsliga systemet var uppbyggt. Eleverna fick lära sig vilka de olika rättsliga instanserna var, vilka lagar som fanns, vilken typ av brott som fanns samt vilka typer av påföljder som fanns. Rättssamhället kunde också visualiseras, exempelvis genom en illustration på en domstolssal eller ett fotografi på poliser som gripit en brottsling. Här formulerades således en idé om normalitet och avvikelse, samtidigt som lagen användes för att skapa en föreställning om att man var del av samma sociala sammanhang: "Lagens majestät står över oss alla; den är vår högsta myndighet. För den måste alla böja sig, konungen såväl som den enkle medborgaren." ${ }^{28}$

Besläktat med detta fokus på lagar var talet om regler. I ett läromedel fick eleven själv visa sina kunskaper om regler i det sociala livet genom att fylla i en tipskupong (1, X eller 2). Uppgiften var att ange rätt beteende för olika situationer. Skulle man exempelvis hälsa med händerna i byxfickorna, genom att nicka eller genom att bocka/niga? Och hur skulle man bete sig när man kom in på en rektorsexpedition respektive när man besökte en biograf? ${ }^{29}$

Denna regeldominerade moraluppfattning blev även visuellt demonstrerad i teckningar som föreställde exempel på föredömligt respektive klandervärt beteende. Teckningar av barn som höll upp dörrar, var prydligt klädda, hälsade genom att ta av mössan och hjälpte tanter över gatan kontrasterades mot bilder på barn som trängde sig före i en kö, läste läxan samtidigt som radion stod på, hade oordning i sin skolbänk och var slarvigt klädda. ${ }^{30}$ Att samhället präglades av en mångfald av regler var något som var påtagligt. Efter att ha gått igenom föreningslivets regler konstaterade en lärobok: "Det är inte bara i föreningar man har regler att följa. Tvärtom finns det

\footnotetext{
26 Rydén (1937), 162.

27 Rosén och Jonsson (1957), 54.

28 Thurén och Lindblom (1956), 28.

29 Barck (1961), 5.

30 Näslund (1955).
} 
på nästan alla områden bestämda regler, som vi inte får bryta mot, om det ska gå bra att vara tillsammans med andra människor." ${ }^{31}$

Lagen och regeln var således central i samhällskunskapens moralförmedling. Genom att uppmärksamma brott, straff och regler förmedlades också en moralsyn där den absoluta moralen stod i centrum. Rätt och fel kunde skiljas åt med lagens/ regelns hjälp, och individens ansvar var följaktligen att lära sig lagarna och att följa dem.

\title{
Tidsuppfattning: framtidsämnet
}

De samhällsorienterande ämnena vilar på en upptäckt av det samtida samhället som studieobjekt. I kontrast till den samhällslära som i läroverken lästes i samband med historia skulle man här studera samtiden. Det gamla tillbakablickandet lämnades till förmån för en skola som försökte bevaka det samtida samhället, exempelvis genom en särskild timme då man skulle diskutera aktuella spörsmål. Denna upptäckt av samtiden byggde också på ett intresse för framtiden.

Poängen med ämnet var att individen skulle utveckla kunskaper som skulle komma till användning i framtiden. Nils Helgers lärobok i medborgarkunskap motiverade ämnet utifrån det faktum att eleverna i framtiden skulle komma att bli deltagare i samhällslivet.

\begin{abstract}
När vi kommer till mogen ålder, får vi ta del i samhällets styrelse. Somliga blir valda till att besluta om samhällets bästa. På våra skolbänkar sitter nu framtidens fullmäktige, landstingsmän och riksdagsmän. De som inte blir valda till så ansvarsfulla uppdrag får i alla fall vara med om att välja sådana förtroendemän. ${ }^{32}$
\end{abstract}

Här är det tydligt att det finns en koppling till 1900-talets demokratisering. Samhällskunskapen blev ett viktigt framtidsämne för att det erbjöd en förberedelse inför deltagandet i ett demokratiskt samhälle. Ett annat uttryck för denna framtidsinriktning återfinns i Den unge medborgaren, som i ett avsnitt om föreningskunskap beskriver en förmodad beundran som skolelever kan känna inför hur de äldre förmår hantera föreningsliv:

Kanske har du beundrat vuxna och äldre kamrater, som känt väl till hur man ska uppträda, när och hur man bör yttra sig osv. Många gånger har du tyckt, att det skulle vara roligt att äga samma säkerhet som de. Föreningsvana får man genom mycken övning. ${ }^{33}$

Författarna föreslog därför att eleverna skulle bilda en klassförening. I början skulle läraren vara ordförande, tills eleverna lärt sig formerna för ett sammanträde. Framtidsinriktningen var också märkbar i form av yrkesvägledning. Samhällskunskapsböcker från 1950-talet vittnar om att steget från skola till yrkesliv inte var långt. Framtiden i form av arbete och yrkesutbildning gjorde sig påmint genom att stort utrymme gavs åt frågan om vidare utbildning, yrke och yrkesval.

31 Blomquist, Pederby och Teng (1960), 38

32 Helger (1955), 5.

33 Thurén och Lindblom (1956), 52. 
Samhällskunskap var en logisk produkt av ett modernt samhälle, präglat av demokratins genombrott och välfärdssamhällets framväxt. Samhällskunskap tillfredsställde det moderna samhällets behov av att bejaka framsteget och framtiden på ett sätt som samtidigt gav utrymme för en moralisk reglering av individen. Livskunskap framträder på ett motsvarande sätt som typiskt för det senmoderna samhällets sätt att utöva makt.

\section{Livskunskap}

Livskunskap är ett ämne som började växa fram i Sverige under 1990-talet, ett decennium då skolpolitiken präglades av decentraliseringsidéer. I Lpo 94 öppnades det upp för ökad valfrihet att skapa egna ämnesprofiler, och livskunskap - som inte återfinns som skolämne i den nationella läroplanen - kan ses som en del av valfriheten. Samtidigt är det ett ämne som relaterar till skolans bredare uppdrag. Pedagogen Camilla Löf konstaterar att livskunskap, enkelt uttryckt, är ett svar på skolans behov av att organisera såväl värdegrundsarbete som undervisning i sex och samlevnad, tobak, alkohol och droger. ${ }^{34}$ Framväxten av ämnet kan också ses som en del av en trend av olika manualbaserade program för att arbeta med psykisk hälsa och värdegrundsfrågor. ${ }^{35}$ I början av 2000-talet utvecklade Birgitta Kimber ett mycket omfattande material för detta ämne, bestående av läromedel och lärarhandledningar omfattande förskoleklass, grundskola och gymnasium. Det är detta material som i det följande analyseras. Idag är intresset för ämnet, av allt att döma, avtagande. Förutsättningarna för ämnet har förändrats sedan dess storhetsdagar. Ämnet har blivit ifrågasatt i granskningar i både TV och radio för att vara integritetskränkande. Förutsättningarna för denna typ av lokalt baserade värdegrundsämnen har också försämrats i takt med att mätbara kunskaper har hamnat mer i fokus för den allmänna debatten, och i takt med att den nationella styrningen av skolan allt mer betonas. Mycket talar därför för att livskunskap i stigande grad bör räknas till det förflutna. Emellertid finns inga studier som undersökt ämnets förekomst på svenska skolor.

Det som utmärker ämnet livskunskap är att det har lanserats som en lösning på en rad olika problem. I likhet med samhällskunskapsämnet är det ett ämne som anses bemöta flera behov. Enligt Birgitta Kimber handlar ämnet livskunskap om att utveckla social och emotionell kompetens, att förebygga mobbning, arbeta med värdegrund, verka för jämlikhet, motverka psykisk hälsa och skapa förutsättningar för inlärning. ${ }^{36}$ Detta ger ämnet en tämligen vag profil, inte minst i jämförelse med andra mer specifika program såsom Lion's Quest och Skol-Komet.

Livskunskap skiljer sig från andra ämnen genom att det saknar stoff i traditionell bemärkelse. Istället genereras ämnets innehåll huvudsakligen av eleverna själva. Det är deras erfarenheter, tankar, värderingar, åsikter och känslor som ämnet kretsar kring. Eleverna får uttrycka sig i olika former: genom personlig skriftlig reflektion, i samtal i mindre och i större grupper, genom rollspel och värderingsövningar etc. I den mån ämnet innehåller stoff är det således något som ryms inom individerna

34 Löf (2011), 14-20.

35 Andreas Bergh et al., Värdepremisser i främjande och förebyggande program i skolan: Rapport från forskningsprojektet En värdefull skola (Örebro: Örebro universitet, 2013).

36 Birgitta Kimber, Att främja barns och ungdomars utveckling av social och emotionell kompetens. 2. uppl. (Malmö: Epago, 2009), 102-5. 
och ämnets kärna kan sägas handla om att locka fram detta. I livskunskap förs samtal som ibland blir personliga, och i vissa övningar är gränsen mot det privata mycket diffus. I ett läromedel för gymnasiet återfinns exempelvis följande fråga: "Skulle du kunna tänka dig att ha sex med en kompis? Motivera ditt svar!"37

I relation till de samtal som förs har ämnet ett antal regler, som enligt Kimber är centrala.

- Man har rätt att säga "pass", det vill säga man behöver inte säga något om man inte vill. Man måste vara med på lektionen men man behöver inte diskutera eller samtala med de andra i gruppen förrän man själv känner sig beredd att göra det.

- En i taget talar. Man stör inte eller pratar i munnen på någon annan. Detta för att visa rerspekt för den som har ordet. Man skrattar eller viskar inte heller då någon annan pratar.

- Det som sägs i rummet stannar i rummet, det vill säga man talar inte om för andra vad någon sagt under livskunskapslektionerna. ${ }^{38}$

Dessa regler, som uppenbarligen är tillkomna för att motverka den risk för integritetskränkning och skvaller som ämnet kan föra med sig, vittnar om ämnets särart. Den första och den tredje av dessa regler bryter markant mot praxis i traditionell skolundervisning.

\section{Moralisk kompetens: känslor}

Det centrala målet i ämnet livskunskap är att eleverna ska utveckla så kallad emotionell intelligens. Med hjälp av ett strukturerat, manualbaserat program, som sträcker sig från 6 till 18 års ålder, ska eleven genomgå så kallad Social och emotionell träning (SET). Emotionell intelligens förstås här som en egenskap som kan tränas upp. Till skillnad från hur intelligensbegreppet traditionellt beskrivits är det alltså inte fråga om en statisk begåvning hos en individ. Men i likhet med det traditionella intelligensbegreppet är inte den emotionella intelligensen jämnt fördelad över befolkningen. Exakt hur fördelningen ser ut beskrivs inte. Istället för en normalfördelningskurva antyds en mer dualistisk modell bestående av de som är, och de som inte är, emotionellt intelligenta. "Emotionellt intelligenta människor söker sällan ytlig njutning utan uppmärksammar sina känslor så att de kan vara till hjälp på vägen mot mognad och växt." Den andra kategorin beskrivs i termer av att de har "brist" på intelligens, vilket kan leda till en oförmåga att planera sitt liv, att man blir nedstämd och lätt blir styrd av sina känslor. ${ }^{39}$ Här ser vi att ämnet bygger på en idé om vinnare och förlorare, och att ämnet antas kunna jämna ut skillnader mellan dessa. "Människor med social och emotionell kompetens klarar sig mycket bättre i livet än andra." 40

Den röda tråden i ämnet handlar om känslor. Det antas att känslor behöver identifieras så att individen blir bättre på att styra dem. Icke-identifierade känslor antas kunna leda i fel riktning. Tanken är med andra ord att känslor ska ta form som något separat inom individen. Först då kan individen ta kontroll över dem.

37 Birgitta Kimber, Livskunskap (Solna: Ekelund, 2002), 81.

38 Kimber (2009), 108.

39 T.ex. Birgitta Kimber, Livsviktigt 10 (Solna: Ekelund, 2001), 10.

40 Kimber (2009), 102. 
Ett viktigt inslag i denna känslodisciplinering rör aggressioner. En övning vid namn "stoppljuset" används för att lära eleverna hur man kontrollerar sina aggressioner, och hur man på så sätt kan kanalisera en ursprunglig aggression till en mer konstruktiv lösning. ${ }^{41}$ Men alla känslor ska inte tryckas ned. Livskunskap bygger också på idén om att känslor ska komma till uttryck. Övningar bygger på att individer lär sig att offentliggöra och verbalisera sina känslor. Känslorna förläggs på så sätt inte bara till en separat del av det egna jaget, de tar också konkret, materiell form utanför individen i form av de texter och bilder som frambringar i den egna elevboken. Detta innebär en form av dokumentation av känslolivet som många kan följa. Enligt Birgitta Kimber: "Därmed dokumenteras deras emotionella och sociala utveckling och den kan följas av såväl föräldrar som lärare och inte minst eleverna själva." ${ }^{42}$ Elevens känslor är med andra ord inte bara en privat angelägenhet, utan något som föräldrar och lärare via läroboken kan få inblick i. I vissa övningar ingår också att muntligt samtala om sina känslor. Hur obligatoriskt detta är varierar - en grundregel är att man alltid har rätt att säga pass - men det finns också bitvis en mer befallande ton där individen förväntas att på beställning berätta om sina känslor. I en övning ska läraren lista en stor mängd känslor på tavlan. Tillsammans väljs fyra känslor ut. I sin bok ska sedan eleverna rita känslouttrycken och skriva exempel på vad som ger respektive känsla. Parvis ska de därefter jämföra vad de skrivit och ritat. Slutligen samlas eleverna i stor grupp, och de som vill får berätta. ${ }^{43}$ Indirekt är detta en övning som tränar eleverna i att se känslor som en offentlig, lika mycket som en privat, del av jaget. Känslor ska identifieras, uttryckas, offentliggöras. Efter offentliggörandet kan de också utvärderas. Visserligen ska inte läraren moralisera, men eleverna uppmuntras att själva utvärdera känslorna.

Manualerna i livskunskap förmedlar också idéer om hur läraren ska agera. Övningarna inleds i regel med att läraren gör en inledning. Här uppmuntras läraren att berätta om sina egna erfarenheter och att vara personlig. "Berätta med inlevelse någon gång då du blivit riktigt arg (ta helst ett exempel då du inte handlade så klokt. Tala om vad du sa och vad du gjorde. Låt barnen hjälpa dig att komma på alternativa handlingssätt och att tänka ut konsekvenserna av dem.)" 44 Tanken tycks vara att läraren ska bryta isen; genom att inleda på ett personligt sätt, uppmuntras även eleverna att vara personliga. Den personliga introduktionen ger läraren en roll som förebild av ett nytt slag. Läraren träder fram som förebild i egenskap av att visa sig svag. Genom att göra en sådan annorlunda introduktion signalerar läraren att livskunskap är ett annorlunda ämne där såväl elever som lärare förväntas att bete sig annorlunda än under vanliga lektioner.

\section{Moralens centrum: individer och socialt samspel}

Livskunskap saknar ambitioner att konstruera stora föreställda gemenskaper. Det är inte ett ämne som syftar till att, sten för sten, bygga en nationskänsla. Snarare kretsar ämnesinnehållet kring individen - dess känslor, värderingar och erfarenheter. I den meningen kan ämnet sägas avspegla och driva på den nedmontering av själva

\footnotetext{
41 Se t.ex. Birgitta Kimber, Livsviktigt 3, lärarhandledning (Solna: Ekelund, 2001), 13.

42 Birgitta Kimber, Livsviktigt 5, lärarhandledning (Solna: Ekelund, 2001), 13.

43 Ibid., övning 16.

44 Birgitta Kimber, Livsviktigt 4 (Solna: Ekelund, 2001), 23.
} 
idén om samhället och den individualism som det senmoderna samhället ofta sägs präglas av. ${ }^{45}$

Detta fokus på individen tar sig flera uttryck. Man får genom värderingsövningar lära sig säga ifrån och att stå för sin åsikt, man tränas i att sätta individuella mål, att berömma sig själv, och att inte falla för grupptryck. Det senare kan exempelvis formuleras på följande sätt i en lärarhandledning: "Samtala med eleverna om hur viktigt det är att kunna säga ifrån när man tycker att något är 'dumt"' - exempelvis att snatta i en affär, röka på toaletten eller reta en kamrat i korridoren. ${ }^{46}$

Men det vore förenklat att enbart beskriva livskunskap som ett individualistiskt skolämne. Det rymmer också en stor portion social träning. Man kan se det som ett ämne som behandlar den sociala samlevnadens problem i ett individualiserat samhälle. I detta avseende är det ett ämne som relaterar till skolans institutionella kännetecken: att det är en plats där det är närmast omöjligt att vara en individ; där man aldrig är ensam. I detta täta sociala sammanhang uppstår det oundvikligen sociala slitningar, vilket skapar ett material som livskunskapsämnet kan relatera till. Intresset för sociala relationer speglar också ett generellt ökat intresse för sociala relationer mellan skolelever som skett under senare decennier. ${ }^{47}$ I en tid som betraktar mobbning, annan form av social aggression och uteslutning som oacceptabel är det inte förvånande att livskunskap hanterar sådan problematik.

Men ämnet bygger samtidigt på en dubbel bild av skolklassen. Denna är inte bara en social enhet där kränkningar förekommer. Skolklassen förutsätts också kunna vara ett sammanhang präglat av tillit och öppenhet - en plats där man fritt kan tala om sina innersta känslor. Som nämnts är en regel att vad som sägs inom klassrummet ska stanna där - eleverna åläggs alltså en form av sekretess. Genom den regeln antyds att ämnet förväntas vara av privat karaktär. Det som sägs inom detta sammanhang förväntas vara problematiskt om det får spridning. Det förutsätter i sin tur att skolklassen antas kunna fungera som ett förtroendefullt forum där man under avslappnade former kan berätta om mer privata sidor av sig själv.

Det finns således både en individualistisk och en social moral inom livskunskapen. Gemensamt för dem båda är ett visst mått av moralisk relativism. För den individualistiska moralen förmedlas ett motsägelsefullt budskap. Ett absolut krav - att vara en individ - samsas med en relativ moral om att alla åsikter ska respekteras. Detta framkommer också i en kommentar i Kimbers handledning, där hon slår fast att tanken med en värderingsövning inte är att komma fram till rätt värdering, utan att "tränas i att stå för sin åsikt och att vända och vrida på sina värderingar och attityder." ${ }^{48}$ Även den socialt inriktade delen av livskunskap opererar med en flexibel moraluppfattning. Snarare än absoluta bud handlar det om att respektera olikheter. Det är ett ämne som söker lära individen att säga ja och nej, och respektera andras ja och nej. Man kan se det som att det inte är några fasta moraliska normer som förmedlas - utan snarare handlar det om att träna upp de dispositioner som gör det möjligt att i ett samspel respektera varandras respektive gränser.

45 Zygmunt Bauman, The Individualized Society (Cambridge: Polity Press, 2001); Zygmunt Bauman, Society Under Siege (Cambridge: Polity Press, 2002); Beck och Beck-Gernsheim (2002).

46 Birgitta Kimber, Livsviktigt 6, lärarhandledning (Solna: Ekelund, 2001), 217.

47 Anna Larsson, "The Discovery of the Social Life of Swedish Schoolchildren," Paedagogica Historica 48, no. 1 (2012), 121-35.

48 Kimber (2009), 131. 


\section{Tidsuppfattning: nutidsämnet}

Livskunskap är ett ämne där nutiden ges större vikt än framtiden. Ämnet hämtar sitt stoff i elevernas aktuella erfarenheter, och målsättningarna relateras sällan explicit till en framtida utveckling. I förordet till ett läromedel i livskunskap för skolår 4 beskrivs ämnets karaktär som starkt skolanpassat. "När du arbetar i den här boken får du träna dig på sådant som är viktigt att kunna både när du ska lära dig något och när du är tillsammans med dina kamrater." Kort exemplifieras det med att eleven får lära känna sig själv, förstå hur andra människor kan känna och tänka, liksom att lösa problem och konflikter människor emellan. Detta knyts inte till framtida behov, utan till de samtida problemen: "Genom att träna på allt detta lär du dig hur du kan göra för att trivas bättre, både med dig själv och med dina kamrater och de vuxna i din omgivning. När du mår bra och trivs med människorna omkring dig går skolarbetet lättare och det blir roligare för dig att vara tillsammans med dina kompisar." ${ }^{39}$ I ett läromedel för gymnasiet motiveras på liknande sätt ämnet i inledningstexten utifrån elevens samtida situation: "Det här ämnet handlar om saker som är viktiga i ditt liv: kärlek, sexualitet, vänskap, att må bra, att kunna kommunicera, hantera relationer och mycket, mycket mer." ${ }^{50}$

\section{Från samhälle till liv: en jämförelse}

Samhällskunskap och livskunskap är två moraliskt fostrande skolämnen som införts i två olika skeden av 1900-talet. Gemensamt för dem båda är att de, i egenskap av nya ämnen, kunnat fungera som behållare för olika typer av fostrande ämnesinnehåll. Ändå är skillnaderna mellan dessa ämnen som vi sett påtagliga. I det följande gör jag en mer systematisk jämförelse mellan ämnena.

\section{Kollektivism och individualism}

Samhällskunskap och livskunskap är båda socialt fostrande skolämnen, men har olika syn på relationen mellan individ och kollektiv. Något tillspetsat kan det formuleras som att samhällskunskap syftade till att stärka kollektivet medan livskunskap syftar till att stärka individen. I samhällskunskap betonades att samhälle betyder sammanhållning - detta var ofta utgångspunkten - och ämnet förmedlade moralen att samhället är starkt, och att individens uppdrag är att bidra till att stärka samhället och gemenskapen. Detta görs genom att underordna sig de skrivna och oskrivna regler som finns i samhället - att följa såväl lagen som far och mor och att utföra olika samhälleliga plikter. Man ska visa samhället vördnad, och detta tränas eleven i genom att samhällets ljusa sidor uppmärksammas. Ämnet var inte explicit ägnat åt emotionell träning, men det fanns alltså här en emotionell komponent som bestod $i$ att individen skulle förmås att känna sympati för samhället. Styrkan i denna emotionella fostran var visserligen inte alls lika stark som den tidigare mer patriotiska fostran som äldre tiders läroböcker förmedlat. ${ }^{51}$ Men likafullt präglades samhällskunskapen av en emotionell komponent. Livskunskapen är mer individorienterad, och det märks inte minst i dess inställning till känslor. Här tränas eleven inte i att älska sitt samhälle, utan snarast att älska sig själv. Inriktningen på det egna självförtroendet är påtaglig. Att berömma sig själv, att språkligt formulera vad man är bra på

49 Birgitta Kimber, Livsviktigt 5 (Solna: Ekelund, 2001), 5.

50 Kimber (2002), 5.

51 Tingsten (1969). 
exemplifierar denna tendens. I livskunskapen tränas också individen i att sätta mål, men till skillnad från samhällskunskapsämnet mål är det inte gemensamma mål som omtalas, utan personliga. Frånvaron av ett kollektivt perspektiv märks också när det handlar om kränkningar. I ämnet finns ett stort fokus på att motarbeta kränkningar, men det är inte den kollektiva kränkningen som står i centrum. Det är således inte angreppet på flaggan eller på lagen som uppmärksammas, utan det är det rent konkreta angreppet på en individ.

Men kontrasten ska inte överdrivas och förenklas. En likhet består i att även samhällskunskapsämnet uppvisade vissa inslag som kan tolkas som individualistiska. Samhällskunskapen gav således även individens rättigheter mycket utrymme. Men framför allt är det påtagligt att livskunskapen rymmer socialt fostrande inslag som går bortom att bara vara en individ. Även om livskunskap är en del av en terapeutisk kultur är det att gå för långt att ensidigt karakterisera ämnet som individualistiskt. ${ }^{52}$ Ämnet är också ett försök att bilda social gemenskap, om än på ett nytt sätt. Övningarna syftar också till att öva hänsyn och förståelse för andra. Att kunna lyssna på andra och att leva sig in i hur andra känner är två återkommande övningar. Individualismen är inte helt asocial. Snarare handlar det om hur individer kan förmås att interagera socialt. Man skulle kunna säga att livskunskapsövningarna syftar till att förmå individer att vara individer inom ramen för ett sammanhang som är allt annat än individualistiskt. Givet att skolan är en plats där individer ständigt är omgivna av andra människor, är livskunskapens en sorts kompromissämne. Det är en form av social uppfostran som uppstår i ett samhälle präglat av individualiseringsprocesser.

\section{Från moralförmedling till personlig moral, gränssättning och patologisering}

En aspekt av denna individualiseringsprocess är hur moral förmedlas. Samhällskunskap byggde på idén om moralförmedling, där moral uttolkades som en fråga om rätt och fel. Denna dualistiska tolkning av moral kunde exempelvis synas i arbetsuppgifter där elever skulle svara på frågor om vett och etikett eller i talet om lag och lagbrott. I livskunskap talas det inte på ett lika övertydligt sätt om moral som en fråga om förmedling av det rätta/felaktiga. Istället riktas uppmärksamheten mot individen som förväntas träna sig $\mathrm{i}$ att göra egna val och att kunna stå för de egna uppfattningarna. Med hjälp av värderingsövningar tränas individen att stå för sin egen mening snarare än att lära sig den allmänna meningen. En viktig aspekt av moralen handlar om det sociala samspelet där individer tränas $i$ att uttrycka och acceptera uttrycken "ja" och "nej". Samtidigt finns det också tydliga inslag av en dualistisk rätt/fel-moral även inom livskunskap. Även om normerna inte hamras fast på ett övertydligt sätt är det ofta uppenbart vad individen förväntas tycka. En uppgift kan här ofta anta formen av ett individuellt val, men genom att frågan ställs förmedlas ett värde, exempelvis om rökning och alkohol, där förmågan att stå emot grupptryck är ett värde medan avhållsamhet från droger är ett annat. Ämnet opererar dessutom med en ny typ av dualism, den mellan friskt/sjukt (emotionella störningar) som inskärper att det finns sätt att tänka, handla och känna som är mer riktiga än andra.

Man kunde möjligen beskriva detta som att skillnaden mellan ämnena är som störst på en retorisk nivå. Samhällskunskap befallde, det talade med utropstecken. Livskunskap talar med frågetecken, och ber individen att utforska sitt inre, men frågans formuleringar antyder vilka svar som är lämpliga.

52 Jfr. Furedi (2004), 91. 


\section{Det närliggande och det avlägsna}

Gemensamt för livskunskap och samhällskunskap är att läromedlen tar utgångspunkt i elevens egna erfarenheter. För samhällskunskapen är detta dock just utgångspunkten. Många böcker börjar med ett kapitel om hemmet, vilket beskrivs som ett samhälle i miniatyr, följt av kapitel om de större samhällsbildningar som man sedan rör sig ut mot: kommunen, staten, och avslutningsvis: internationell, fredlig samverkan. Ämnet i stort får sin prägel av denna resa från det närliggande till det fjärran. Anknytningen till individens erfarenheter används således som språngbräda för att göra nya erfarenheter utanför individens värld, såväl i tid som i rum. I livskunskap är det närliggande viktigt på ett annat sätt. Individernas erfarenheter, känslor och tankar är inte en språngbräda mot andra världar, utan utgör istället det material som hela ämnet bygger på. Idén är inte att börja i det närliggande för att kunna lämna det. Snarare börjar man och slutar på en och samma punkt, med skillnaden att man borrar sig djupare ned i det egna jaget.

I livskunskap är klassrummet dessutom en avgränsad plats. Undervisningen omgärdas med krav på sekretess för eleverna: vad som sägs i klassrummet ska stanna i klassrummet. I kontrast mot samhällskunskapens koncentriska samhällsbild, har livskunskapen en "klassrums-centrisk" världsbild. Det är en cirkel som sluter sig snarare än att ge ringar på vattnet. I en egenartad kombination av hemligheter och offentligheter upprättas inom klassrummet ett rum som både är privat och offentligt. Lektionerna går ut på att locka fram - offentliggöra - det innersta i eleverna, och när det väl offentliggjorts ska det göras om till en hemlighet som stannar i klassrummet.

Man kunde beskriva det som att livskunskapen gör jaget till kunskapsobjekt, medan samhällskunskapen gör världen till kunskapsobjekt. Att känna sig själv, sina känslor och värderingar, och att stå för dem, är centralt inom livskunskapen, medan samhällskunskapen arbetade med att känna världen. Att samhällskunskapen verkligen var annorlunda kan illustreras genom ett läromedel som vid ytligt påseende kunde uppfattas som terapeutiskt.

I ett elevhäfte med arbetsuppgifter i samhällskunskap från 1964 återfinns rubriken "Känn dig själv!" Formuleringen låter nästan som om den skulle kunna finnas i en bok i livskunskap. Men vid närmare granskning framträder särarten. Uppgiften har ingenting med en mer sentida terapeutisk pedagogik att göra. Rubriken återfinns, typiskt nog, i kapitlet "Yrkesvalet." ${ }^{53}$ Att välja yrke var en viktig del av samhällskunskapen, och eleverna tränades inte minst $\mathrm{i}$ att göra självständiga val som var i samklang med både det egna intresset och den egna förmågan. Valet skulle med andra ord inte bestämmas av föräldrars preferenser eller av kamraters inflytande. Eleven behövde hitta sig själv: sin vilja och sin förmåga. Att samhällskunskapens idé om att hitta sig själv var kopplad till yrkesvalet innebar ett framtidsfokus. Det egna jaget var framförallt intressant inom ramen för en förändringsprocess. Man behövde lära känna sig själv för att veta vem - eller snarare vad - man skulle bli. Att lära känna sig själv handlade om att lära sig sina fysiska och mentala begränsningar.

Frågan om det närliggande och det avlägsna var också kopplad till mognadens problematik. Ett ofta outtalat antagande i diskursen om de samhällsorienterade ämnena var barndoms- och ungdomstidens isolering från (det vuxna) samhället. Själva syftet med undervisningen var att skapa kunskap och en positiv inställning till en

53 Björkblom (1963), 16. 
social kontext som eleverna inte ansågs fullt ut vara del av. Elevernas isolering från samhället skapade en risk för att de på ett problematiskt sätt tydde sig till "gänget." I en artikel om samhällsorientering i den högre skolan beskrevs detta förhållande uttryckligen som ett problem, och undervisningen skulle därför försöka bryta isoleringen. "Man bör sträva efter att låta eleverna leka vuxna, d.v.s. acceptera deras innersta önskan att vara vuxna. Leken måste vara allvarsbetonad för att fiktionen inte skall bryta igenom alltför lätt." ${ }^{54}$ Klassen kunde exempelvis få bilda en klubb och utse ordförande eller starta sin egen tidning. Inom ämnet livskunskap finns också ett tal om mognad, men som vi sett är framtidsinriktningen inte alls lika påtaglig, och ämnet förefaller framför allt ägnat åt att få situationer i nuet att fungera, och snarare än att försöka bryta klassens isolering, är övningarna av den karaktären att de stannar i klassrummet. I kontrast till klassens tidning - ett försök att kommunicera med omvärlden - har livskunskapen regeln att vad som sägs i klassrummet stannar i klassrummet.

\section{Diskussion: modernisering, vakuum och moralisk fostran}

I den här artikeln har två moraliskt fostrande skolämnen beskrivits och jämförts. Genom att studera två ämnen som kan knytas till två olika tidsperioder har jag velat belysa hur skolans moraliska fostran via dess skolämnen kan förmedla normer som är i samklang med den tidsanda i vilken de växer fram. Genom den komparativa ansatsen har ambitionen varit att synliggöra vissa dimensioner av respektive ämne som annars tenderar att bli mindre synliga. Avslutningsvis vill jag på ett mer övergripande plan reflektera över hur förskjutningen från samhällskunskap till livskunskap kan förstås. Jag vill föreslå att båda dessa ämnen delvis kan förstås som resultat av de kunskapsmässiga vakuum som uppstår i samband med omfattande samhällsförändringar.

Samhällskunskap som ett moraliskt fostrande ämne växte fram parallellt med att kristendomen började spela en mer undanskymd roll i skola och samhälle. Dess moral var inte helt överspelad, men den hade upphört att vara heltäckande. I dess ställe inträdde bland annat Samhället, som blev en viktig referenspunkt som moralisk fostran kunde orientera sig mot. Medan traditionell fostran kretsat kring att respektera Gud kom den moderna, sekulariserade varianten att förespråka en respekt mot samhället. Detta fokus på individen som samhällsvarelse byggde på att själva idén om ett samhälle konkretiserades och utmålades som någonting allestädes närvarande. Genom samhällskunskapens koncentriska bild av samhället förmedlades bilden av att samhället var något som fanns överallt - från hemmet till världssamfundet. Att man på så sätt ersatte Gud med Samhället som moraliskt rättesnöre innebar också att skolämnet på ett tydligare sätt kunde inordnas i en framstegsberättelse. Att visa respekt för samhället blev liktydigt med att medverka i det stora framstegsprojekt som det moderna samhället stod för. Samhällskunskap blev ett ämne som präglades av den moderna tanken om sociala framsteg. Denna framstegstanke byggde delvis på att sekulariseringen lösgjorde kristendomens grepp om den moraliska fantasin. Filosofen Émile Cioran har pekat på relationen mellan utopism och sekulärt tänkande: "Så länge sinnena var uppfyllda av kristendomen kunde utopin inte fresta människ-

54 Olof Thörn, "Några former av samhällsorientering i den högre skolan," i Social fostran, red. E. Hermansson (Stockholm: Svenska bokförlaget Bonniers, 1952), 255. 
orna, men så snart de började bli besvikna på den försökte utopin vinna inflytande över dem och nästla sig in hos dem. [...] Sålunda föddes Framtiden, en vision om den oåterkalleliga lyckan, om ett reglerat paradis där slumpen inte har någon plats, där minsta tecken på fantasi betraktades som kätteri eller provokation." ${ }_{55}$

Om samhällskunskap kan relateras till det vakuum som sekulariseringen frambringar, hur kan då framväxten av livskunskap förstås? En möjlig tolkning är att livskunskap växer fram i en tidsperiod när samhället förlorat en stor del av sitt forna grepp om människor, när själva idén om samhället börjar framstå som diffus och fjärran från dess medborgare. ${ }^{56}$ Som vi har sett är livskunskap ett ämne som opererar utan hänsyftning till någon social enhet som är större än de mer socialpsykologiska situationer i vilken individen själv ingår i. Ämnet är fokuserat på den närmaste omgivningen och de relationer som denna består av, och riktar i övrigt sitt fokus mot individen och dess känsloliv.

Det kan tyckas vara en relativt snäv form av moralisk fostran, men trots detta bär den ett mycket anspråksfullt namn: livskunskap. Hur kan vi då förstå villkoren för ämnets framväxt? Vad säger det om samtiden att ett moraliskt fostrande ämne spred sig som en löpeld under 2000-talets första år, trots att det saknar explicita hänvisningar till det som tidigare var kärnan i uppfostran: idén om ett samhälle? En möjlig förklaring kan sökas i breda sociala och kulturella förändringar i samhället generellt, där samhället framstår som svårgripbart och omöjligt att påverka, vilket bereder mark för en terapeutisk kultur. ${ }^{57}$ En relaterad förklaring kan ta fasta på det som är specifikt för skolans förändrade position i dagens kunskapssamhälle. Barn och ungdomar går allt längre i skola. Därmed har skol- och ungdomstiden förlängts och inträdet i vuxenvärlden har skjutits framåt. Att ett ämne som livskunskap ägnar så stor energi åt livet i skolan blir delvis begripligt mot bakgrund av denna utsträckning av skoltiden. I ett samhälle där en stor del av livet levs i skolan, är det kanske inte helt slumpmässigt eller missvisande att ett ämne som framförallt handlar om att lära sig att bli en skötsam elev, heter livskunskap.

55 Émile Cioran, Historia och utopi (Stockholm: Brutus Östlings bokförlag Symposion, 1992), $130 f$. 56 Jfr. Zygmunt Bauman, Liquid Modernity (Cambridge: Polity, 2000).

57 Ecclestone och Hayes (2009). 


\section{Referenser \\ Tryckta källor}

Arvidson, Stellan och Karl Lindblom. Samhällskunskap för skolans avslutningsklasser. Stockholm: Svenska bokförlaget/Bonniers, 1953.

Barck, Sven-Eric. Arbetsbok i samhällskunskap. D. 1, Skolan, hemmet, fritiden: för årskurs 7 i enhetsskolan. Gävle: Skolförlaget, 1961.

Barck, Sven-Eric. Arbetsbok i samhällskunskap. D. 2, Arbetslivet, kommunerna, världsproblemen: För årskurs 8 i grundskolan. Gävle: Skolförlaget, 1965.

Björkblom, Sixten och Arnold Helgesson. Samhällsundervisningen: Studieplan $i$ samhällskunskap för sjunde-nionde skolåren vid pedagogisk försöksverksamhet $i$ enlighet med beslut av 1950 års riksdag. Stockholm: Sv. Bokförlaget, 1952.

Björkblom, Sixten. Vårt svenska samhälle: Lärobok i samhällskunskap. Stockholm: Almqvist \& Wicksell, 1953.

Björkblom, Sixten. Samhällskunskap för grundskolan. Årskurs 7, Elevhäfte. Stockholm: Almqvist \& Wiksell, 1964.

Blomquist, Sixten, Henry Pederby och Algot Teng. Samhällskunskap för enhetsskolan och folkskolan: Årskurs 4-6. 2. uppl. Stockholm: Bergvall, 1960.

Bäcklin, Martin och Axel Runestam. Samhällskunskap: Arbetsuppgifter. För årskurs 7. Stockholm: Skrivrit, 1961.

Bäcklin, Martin och Axel Runestam. Samhällskunskap: Arbetsuppgifter. För årskurs 8. Stockholm: Skrivrit, 1963.

Elgeskog, Valter, Olof Skarhed och Karl Lindblom. Barnen möter samhället: Handledning vid undervisning i samhällskunskap på folkskolans och enhetsskolans mellanstadium: [klasserna 4-6]. Stockholm: Svenska bokförlaget/Bonnier, 1955

Fransson, Evald. Demokratins samhälle: Lärobok i samhällskunskap för folkskolans och enhetsskolans högstadium samt för real- och flickskolor. Stockholm: Natur \& Kultur, 1956.

Helger, Nils. Medborgarbok för ungdomsskolor. Under medverkan av Bengt Helger och Torsten Helger, 39. uppl. Uppsala: Lindblad, 1955.

Johannesson, Gösta. Vårt samhälle: Lärobok i samhällskunskap för realskolan och enhetsskolans högstadium. Lund: Gleerups, 1953.

Kimber, Birgitta. Livsviktigt 1-10. Serie om elevböcker och lärarhandledningar. Solna: Ekelund, 2001.

Kimber, Birgitta. Livskunskap. Solna: Ekelund, 2002.

Kimber, Birgitta. Att främja barns och ungdomars utveckling av social och emotionell kompetens. 2 uppl. Malmö: Epago, 2009.

Näslund, Rune. Vi och vårt samhälle: Samhällskunskap för klasserna 4-6. 4. uppl. Stockholm: Carlson, 1955.

Pettersson-Pederby, Henry. Folkskolans samhällslära: klass 7-8 jämte fortsättningsskolan. 2 uppl. Stockholm: Svenska bokförlaget, Norstedts, 1954.

Rydén, Värner. Medborgarkunskap för fortsättnings- och andra ungdomsskolor. 8. uppl. Stockholm: Norstedts, 1937.

Rosén, Arvid och Oscar Jonsson. Samtal om samhället: Samhällskunskap för klass 4-6. 2. uppl. Stockholm: Svenska bokförlaget/Norstedt, 1957.

Severin, Roland och Thorbjörn Rippe. Samhällsboken: Samhällskunskap för grundskolan. Årskurs 4-6. Stockholm: Svenska bokförlaget/Bonniers, 1963. 
SOU 1948:27, 1946 års Skolkommissions betänkande med förslag till riktlinjer för det svenska skolväsendets utveckling. Stockholm: Ecklesiastikdepartementet 1948.

Thurén, Erik och Lars Lindholm. Den unge medborgaren: Lärobok i samhällskunskap för folkskolans och enhetsskolans högstadium. 15. omarb.uppl. Stockholm: Bergvalls, 1956.

Thörn, Olof. "Några former av samhällsorientering i den högre skolan.” I Social fostran, red. E. Hermansson. Stockholm: Svenska bokförlaget Bonniers, 1952.

\section{Litteratur}

Ammert, Niklas, red. Att spegla världen: Läromedelsstudier i teori och praktik. Lund: Studentlitteratur, 2011.

Bartholdsson, Åsa och Eva Hultin, red. Sociala relationer, värdegrund och lärarprofessionalitet. Malmö: Gleerup, 2015.

Bauman, Zygmunt. Liquid Modernity. London: Polity Press, 2000.

Bauman, Zygmunt, The Individualized Society. Cambridge: Polity Press, 2001.

Bauman, Zygmunt. Society Under Siege. Cambridge: Polity Press, 2002.

Beck, Ulrich och Elisabeth Beck-Gernsheim. Individualization: Institutionalized Individualism and Its Social and Political Consequences. London: SAGE, 2002.

Becker, Howard S. Utanför: Avvikandets sociologi. Lund: Arkiv, 2006.

Bergh, Andreas, Anna-Lena Englund, Tomas Englund, Ingemar Engström och Karin Engström. Värdepremisser i främjande och förebyggande program i skolan: rapport från forskningsprojektet En värdefull skola. Örebro: Örebro universitet, 2013.

Bromsjö, Birger. Samhällskunskap som skolämne: målsättningar, kursinnehåll och arbetssätt på den grundläggande skolans högstadium. Stockholm: Stockholms universitet, 1965.

Cioran, Émile. Historia och utopi. Stockholm: Brutus Östlings bokförlag Symposion, 1992.

Dahlstedt, Magnus, Andreas Fejes och Elin Schönning. "The Will to (De)liberate: Shaping Governable Citizens Through Cognitive Behavioural Programmes in School, Journal of Education Policy 26, no. 3 (2011), 399-414.

Ecclestone, Kathryn och Dennis Hayes. The Dangerous Rise of Therapeutic Education. Abingdon, Oxon: Routledge, 2009.

Elmersjö, Henrik Åström. Norden, nationen och historien: Perspektiv på föreningarna Nordens historieläroboksrevision 1919-1972. Lund: Nordic Academic Press, 2013.

Englund, Tomas. Läroplanens och skolkunskapens politiska dimension. Göteborg: Daidalos, 2005.

Englund, Tomas. Samhällsorientering och medborgarfostran i svensk skola under 1900-talet. Del 1-2. Uppsala: Pedagogiska institutionen, Uppsala universitet, 1986.

Evans, Ronald W. The Social Studies Wars: What Should We Teach the Children? New York: Teachers College Press, 2004.

Furedi, Frank. Therapy Culture: Cultivating Vulnerability in an Uncertain Age. London: Routledge, 2004.

Furedi, Frank. Socialisation as Behaviour Management and the Ascendancy of Expert Authority [elektronisk resurs]. Amsterdam: Vossiuspers UvA. Tillgänglig på Internet: http://dare.uva.nl/document/165424, 2009. 
Giddens, Anthony. Modernity and Self-Identity. London: Polity Press, 1991.

Holmén, Janne. Den politiska läroboken: Bilden av USA och Sovjetunionen i norska, svenska och finländska läroböcker under kalla kriget. Uppsala: Acta Universitatis Upsaliensis, 2006.

Irisdotter Aldenmyr, Sara. "Lärarprofessionen och arbetet med livskunskap i grundskolan." Utbildning \& Demokrati 19, no. 2 (2010), 39-57.

Jackson, Philip W. Life in Classrooms. New York: Holt, Rinehart \& Winston, 1968.

Johnsson Harrie, Anna. Staten och läromedlen: En studie av den svenska statliga förhandsgranskningen av läromedel 1938-1991. Linköping: Linköpings universitet, 2009.

Landahl, Joakim. "The Eye of Power(-lessness): On the Emergence of the Panoptical and Synoptical Classroom," History of Education 42, no. 6 (2013), 803-21.

Larsson, Anna. "Samhällskunskap." I Utbildningshistoria: En introduktion, red. Esbjörn Larsson och Johannes Westberg, 249-58. Lund: Studentlitteratur, 2011.

Larsson, Anna. "The Discovery of the Social Life of Swedish Schoolchildren." Paedagogica historica 48, no. 1 (2012), 121-35.

Ljunggren, Jens. Kroppens bildning: Linggymnastikens manlighetsprojekt 1790-1914. Eslöv: Symposion, 1999.

Löf, Camilla. Med livet på schemat: om skolämnet livskunskap och den riskfyllda barndomen. Lund: Lunds universitet, 2011.

Tegborg, Lennart. Folkskolans sekularisering 1895-1909: Upplösning av det administrativa sambandet mellan folkskola och kyrka i Sverige. Uppsala: Studia historico-ecclesiastica Upsaliensia, 1969.

Thelin, Bengt. Exit eforus: Läroverkens sekularisering och striden om kristendomsundervisningen. Stockholm: LiberLäromedel/Utbildningsförlaget, 1981.

Tingsten, Herbert. Gud och fosterlandet: Studier i hundra års skolpropaganda. Stockholm: Norstedts, 1969.

Österlind, Eva. Disciplinering via frihet: Elevers planering av sitt eget arbete. Uppsala: Acta Universitatis Upsaliensis, 1998. 